\title{
A SCREENING TEST FOR HETEROPHILE ANTIBODIES IN INFECTIOUS MONONUCLEOSIS
}

\author{
BY \\ JOHN VAUGHN \\ From the Department of Pathology, St. Bartholomew's Hospital, London
}

SD.

(RECEIVED FOR PUBLICATION OCTOBER 23, 1950)

When Paul and Bunnell (1932) demonstrated the increased titre of heterophile antibodies in the sera of patients with infectious mononucleosis they did so by using the technique devised by Davidsohn $(1929,1930,1933)$ when he was investigating these antibodies in serum sickness. It was also used by other workers who sought to confirm the findings of Paul and Bunnell (Bernstein, 1934; Van Ravenswaay, 1934; Davidsohn and Walker, 1935). In 1935 Davidsohn amended his technique slightly, and in 1937, after there had been further work done on the effect of adsorption on these antibodies by Stuart, Griffin, Fulton, and Anderson (1936), by Stuart, Welch, Cunningham, and Burgess (1936), and by others, he suggested a preliminary adsorption of the sera with various antigens before titration with yet another adaptation of his method. Finally, Barrett (1941) described the technique of absorption and titration which is now widely used.

Attempts have been made to shorten the test by Butt and Foord (1935), Straus (1936), Gleeson-White (1941), and Kaufman (1944), and recently Moloney and Malzone (1949) described a simple slide test which merits further attention. In this test $0.1 \mathrm{ml}$. of defibrinated sheep's red cells are added to $0.2 \mathrm{ml}$. of the serum to be tested on a tile, inactivation not being necessary. The test is considered positive if there is gross clumping of the cells in 30 to 60 seconds. The authors state that false positive tests may be obtained with cold agglutinins and with Forssman antibodies. The former can in almost all cases be excluded by performing the test at $37^{\circ} \mathrm{C}$. and the latter by adsorption with guinea-pig kidney and subsequent titration. This test, because of its simplicity, would appear to have a possible value in screening suspected sera, thus saving some of the time and labour demanded by the full Paul-Bunnell test. With this in view, a number of sera were examined by both the slide test and the PaulBunnell test in an attempt to estimate its reliability.

\section{Method}

The method of Moloney and Malzone was used with minor modifications. It was found unnecessary to measure accurately cells and serum, drops from a Pasteur pipette being adequate for the purpose. Maloney and Malzone used undiluted sheep's cells, but, even with the recommended ratio of 2 to 1 of serum to cells, rouleaux formation proved to be troublesome, so a suspension of cells in saline was used. The test was now carried out as follows.

To one drop of unheated, undiluted serum on a tile was added one drop of a $10 \%$ suspension of sheep's cells. These were well mixed and the tile gently rocked. Clumping of 
the cells within 60 seconds was regarded as a positive result. The test was carried out at room temperature.

\section{Results}

Two hundred and sixty-nine sera were examined by the slide test followed by a Paul-Bunnell test by the method of Davidsohn (1929), which is in use in this laboratory. Of these 17 were sera from cases of infectious mononucleosis diagnosed as such on both clinical and haematological grounds (Table I). Of the remaining 252 sera some were from normal pregnant women and prospective blood donors whose blood

TABLE I

Results of Sera of Infective Mononucleosis Examined by Slide and Paul-Bunnell Tests

\begin{tabular}{c|c|c}
\hline Serum No. & Slide Test & Paul-Bunnell Test (maximum titre) \\
\hline 1 & + & $1: 1024$ \\
2 & + & $1: 2048$ \\
3 & + & $1: 256$ \\
4 & + & $1: 360$ \\
5 & + & $1: 64$ \\
6 & + & $1: 128$ \\
7 & + & $1: 1024$ \\
8 & + & $1: 512$ \\
9 & + & $1: 128$ \\
10 & + & $1: 128$ \\
11 & + & $1: 64$ \\
12 & + & $1: 256$ \\
13 & + & $1: 512$ \\
15 & + & $<1: 16$ \\
16 & + & \\
17 & Negative & \\
\hline
\end{tabular}

TABLE II

Results of Sera of Various Clinical Conditions and Normals Tested by Slide and Paul-BunNell Tests

\begin{tabular}{|c|c|c|c|c|c|c|}
\hline \multirow[b]{2}{*}{ Clinical Condition } & \multirow[b]{2}{*}{ Total } & \multirow{2}{*}{$\begin{array}{c}\text { Positive } \\
\text { Slide Test }\end{array}$} & \multicolumn{4}{|c|}{ Paul-Bunnell Test } \\
\hline & & & $1: 8$ or less & $1: 16$ & $1: 32$ & $1: 64$ \\
\hline $\begin{array}{l}\text { Normal pregnancy } \\
\text { Blood donors } \\
\text { Other normals } \\
\text { Syphilis (W.R. positive) } \\
\text { Cancer } \\
\text { Cirrhosis of liver } \\
\text { Lymphatic leukaemia } \\
\text { Lymphosarcoma } \\
\text { Reticulosarcoma } \\
\text { Hodgkin's disease } \\
\text { Generalized lymphadenitis } \\
\text { Sarcoidosis } \\
\text { Banti's syndrome } \\
\text { Haemolytic anaemia } \\
\text { Rh antibodies } \\
\text { Miscellaneous }\end{array}$ & $\begin{array}{r}114 \\
25 \\
11 \\
4 \\
4 \\
2 \\
1 \\
2 \\
2 \\
1 \\
2 \\
4 \\
1 \\
79\end{array}$ & $\begin{array}{l}\text {,' } \\
\text {,' } \\
\text {,' } \\
\text {,' } \\
\text {,' } \\
\text {,' } \\
\text {,' }\end{array}$ & $\begin{array}{r}75 \\
20 \\
11 \\
4 \\
4 \\
2 \\
1 \\
2 \\
2 \\
1 \\
2 \\
2 \\
1 \\
59\end{array}$ & $\begin{array}{c}26 \\
3 \\
\text { None } \\
,, \\
,, \\
,, \\
,, \\
,, \\
,, \\
\text { None } \\
9\end{array}$ & $\begin{array}{c}13 \\
2 \\
\text { None } \\
,, \\
,, \\
,, \\
,, \\
,, \\
, ", \\
\text { None } \\
11\end{array}$ & $\begin{array}{l}\text { None } \\
\text {,", } \\
\text {,", } \\
\text {,", } \\
\text {," } \\
\text {," }\end{array}$ \\
\hline Total & 252 & , & 186 & 39 & 27 & , \\
\hline
\end{tabular}


had been sent to the laboratory for Wassermann testing. The remainder were obtained from patients in the wards of the hospital, and represent a wide variety of clinical conditions some of which are detailed in Table II.

Considering a titre of $1: 64$ to be a positive Paul-Bunnell test (Bunnell, 1933), it will be seen that, in all cases where the slide test was positive, a positive Paul-Bunnell test was also recorded. The case of infectious mononucleosis which gave a negative result by the slide test proved to have a negative Paul-Bunnell test. In no case where the slide test was negative did the titre of antibodies exceed $1: 32$. It would appear that as the antibody titre approaches $1: 64$ so the slide test becomes positive. There does not appear to be any correlation between the degree of clumping of the cells and the antibody titre. Moloney and Malzone reported false positive tests in cases of cirrhosis of the liver and in haemolytic syndromes. This was not found in similar cases examined in the present series.

\section{Summary}

Attention is drawn to a slide test for heterophile antibodies in infectious mononucleosis, and some minor modifications are suggested.

In 16 sera which gave positive Paul-Bunnell tests the slide test was also positive.

Two hundred and fifty-two sera from normal subjects and from cases other than infectious mononucleosis were tested and found to have both negative slide tests and negative Paul-Bunnell tests.

It is suggested that the procedure described is a quick and easy test which could be used to screen sera sent to the laboratory for Paul-Bunnell testing. A positive slide test would indicate that the full Paul-Bunnell test should be carried out.

Barrett, A. M. (1941). J. Hyg., Camb., 41, 330.

Bernstein, A. (1934). J. clin. Invest., 13, 419.

Bunnell, W. W. (1933). Amer. J. med. Sci., 186, 346.

Butt, E. M., and Foord, A. G. (1935). J. Lab. clin. Med., 20, 538.

Davidsohn, I. (1929). J. Immunol., 16, 259.

- (1930). Ibid., 18, 31 .

- (1933). J. infect. Dis., 53, 219.

- (1935). Amer. J. Dis. Child., 49, 1222.

— (1937). J. Amer. med. Ass., 108, 289.

- and Walker, P. H. (1935). Amer. J. clin. Path., 5, 455.

Gleeson-White, H. (1941). Personal communication quoted in Disorders of the Blood, by Whitby, L. E. H., and Britton, C. J. C., 4th ed. (1942), p. 455.

Kaufman, R. E. (1944). Ann. intern. Med., 21, 230.

Moloney, W. C., and Malzone, L. (1949). Blood, 4, 722.

Paul, J. R., and Bunnell, W. W. (1932). Amer. J. med. Sci., 183, 90.

Straus, R. (1936). Amer. J. clin. Path., 6, 546.

Stuart, C. A., Griffin, A. M., Fulton, M., and Anderson, E. G. E. (1936). Proc. Soc. exp. Biol., N.Y., 34, 209.

Welch, H., Cunningham, J., and Burgess, A. M. (1936). Arch. intern. Med., 58, 512.

Van Ravenswaay, A. C. (1934). New Engl. J. Med., 211, 1001. 